\title{
Developmental Influences on Medically Unexplained Symptoms
}

\author{
C.A. Tony Buffington \\ Ohio State University Veterinary Hospital, Columbus, Ohio, USA
}

\section{Key Words}

Medically unexplained symptoms $\cdot$ Prenatal

programming $\cdot$ Epigenetic modulation $\cdot$ Chronic disease

\begin{abstract}
Background: Medically unexplained (or 'functional') symptoms (MUS) are physical symptoms that prompt the sufferer to seek healthcare but remain unexplained after an appropriate medical evaluation. Examples of MUS also occur in veterinary medicine. For example, domestic cats suffer a syndrome comparable to interstitial cystitis, a chronic pelvic pain syndrome of humans. Method: Review of current evidence suggests the hypothesis that developmental factors may play a role in some cases of MUS. Maternal perception of a threatening environment may be transmitted to the fetus when hormones cross the placenta and affect fetal physiology, effectively 'programming' the fetal stress response system and associated behaviors toward enhanced vigilance. After birth, intense stress responses in the individual may result in similar vulnerability, which may be unmasked by subsequent stressors. Results: Epigenetic modulation of gene expression (EMGEX) appears to play a central role in creation of this 'survival phenotype'. The recent development of techniques to identify the presence of EMGEX provides new tools to investigate these questions, and drugs and other interventions that may reverse EMGEX are also under active investigation. Conclusion: Viewing MUS from the perspective of underlying developmental influences involving EMGEX that affect function of a variety of organs based on familial (genetic and environmental) predispositions
\end{abstract}

rather than from the traditional viewpoint of isolated organoriginating diseases has at least two important implications: it provides a parsimonious explanation for findings heretofore difficult to reconcile, and it opens whole new areas of investigation into causes and treatments for this class of disorders.

Copyright $\odot 2009$ S. Karger AG, Basel

\section{Introduction}

Medically unexplained (or 'functional') $[1,2]$ symptoms (MUS) are a major public health problem. They have been defined [3] as 'physical symptoms that prompt the sufferer to seek healthcare but remain unexplained after an appropriate medical evaluation'. The MUS are also common, affecting as many as one third of people seeking medical care [4]. They may be disabling to those afflicted by them, and often result in increased health resource utilization, loss of productivity, and frustration on the part of both the patient and the clinicians caring for them. Most of the medical subspecialties are presented with patients suffering at least one MUS [5], although controversy concerning the definition and categorization of these disorders exists [6]. Commonalities across the different MUS include over-representation of females, history of adverse early experiences, sudden onset (often

Supported by the National Institutes of Health P50 DK64539 Women's Health and Functional Visceral Disorders Center.

\begin{tabular}{ll}
\hline KARGER & ๑ 2009 S. Karger AG, Basel \\
Fax +41613061234 & \\
$\begin{array}{l}\text { E-Mail karger@karger.ch } \\
\text { www.karger.com }\end{array}$ & $\begin{array}{l}\text { Accessible online at: } \\
\text { www.karger.com/pps }\end{array}$
\end{tabular}

C.A. Tony Buffington, DVM, PhD, Professor of Veterinary Clinical Sciences Ohio State University Veterinary Hospital 601 Tharp Street

Columbus, OH 43210-1089 (USA)

Tel. +1 614292 3551, Fax +1 614292 0895, E-Mail Buffington.1@osu.edu 


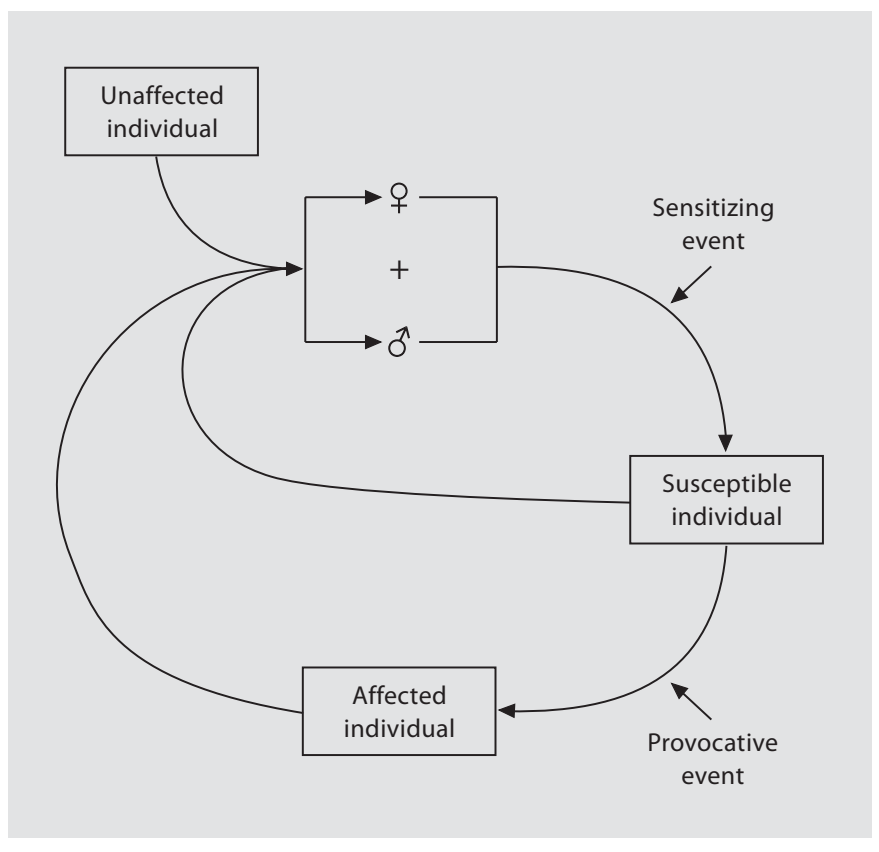

Fig. 1. Proposed pathways to development of medically unexplained symptoms. An unaffected individual mates with another individual, which results in a pregnancy. Either parent may transmit stress susceptibility if it is present in their genome, or it may appear from the resultant genome of the offspring. Additionally, genetic predisposition of the mother to stress susceptibility may increase the likelihood of her transmitting her response to a sensitizing event to the fetus. This pregnancy may result in susceptible offspring, whose stress response to a provocative event may result in an affected individual. This cycle may be repeated and even amplified across generations by these offspring, who have an increased likelihood to pass their vulnerability on to succeeding generations.

after a precipitating event such as an injury or infection), multiple comorbid MUS in the same individual with no obvious pattern or order of onset, waxing and waning course, altered stress response system function (generally including altered adrenocortical and sympathetic nervous system function during stressful periods), and resistance to current therapeutic approaches. These commonalities have led some to suggest the presence of a common underlying cause for the MUS $[1,7,8]$.

\section{Method}

Evidence for Early Influences on MUS

Evidence from clinical, epidemiological, and experimental observations has led to development of theories about how evolutionarily conserved developmental processes interact with envi- ronmental cues (often transmitted from the mother via the placenta) to attempt to match the physiology of the developing organism to its postnatal environment. Some cases of cardiovascular, type-2 diabetes mellitus and the metabolic syndrome, and respiratory and mood disorders have now been shown to result from a mismatch between the predicted and actual environment an organism inhabits [9], and the available evidence suggests that some of the MUS also may be influenced by early life experiences [10].

Converging lines of research suggest that when a pregnant female is exposed to a sufficiently harsh stressor, the hormonal products of the ensuing stress response may cross the placenta and affect the course of fetal development [11], resulting in durable changes in brain [12], autonomic [13], endocrine [11] and immune function [14]. While of potential survival value, these changes also appear to increase vulnerability to life stressors, putting these individuals at greater risk of developing disorders characterized by pain and discomfort $[15,16]$ in some environments.

Additionally, genetic variability in the pattern and magnitude of each of these responses occurs among individuals [17-20], so the final pattern of the stress response may be variable in outbred populations [21]. This pattern also may depend on the salience and threat potential of environmental stressors to the individual, and is likely to be more similar to responses in closely related family members than to unrelated individuals with similar symptoms (fig. 1).

\section{Results}

\section{Potential Mechanisms of Early Influence}

Recent research suggests that one mechanism underlying the sensitization of the stress response system involves a process called epigenetic modulation of gene expression (EMGEX) [22, 23]. EMGEX is a prominent candidate mechanism for the identified differences in stress responsiveness found in patients with MUS because it has been shown to occur in the offspring of pregnant females exposed to stressors [24, 25], and to result in long-term neuroendocrine abnormalities [24, 26].

My introduction to MUS came through studies of interstitial cystitis (IC), a chronic pelvic pain syndrome of unknown cause and no generally accepted treatment [27]. Patients with IC also present with a variety of other medical problems, including chronic pelvic pain [28], irritable bowel syndrome [29], and chronic fatigue syndrome/fibromyalgia [30, 31]. Moreover, a clinical and genetic link between IC and panic disorder, social anxiety disorder and mitral valve prolapse has been reported $[32,33]$.

A syndrome similar to IC also occurs in domestic cats, which has been called feline IC (FIC) [34]. Cats with FIC meet all of the inclusion and exclusion criteria for diagnosis of IC that can be applied to animals [35]. IC in hu- 
mans and FIC in cats are remarkably similar; patients of both species have abnormalities of local bladder factors, visceral afferent pathways, the central nervous system, hypothalamic and gonadal hormone systems, and the sympathetic nervous system [36]. In addition to bladder problems, studies have shown that cats with FIC also have variable combinations of gastrointestinal, metabolic, cardiovascular, autonomic and behavioral symptoms [3638]. As in humans, no discernable pattern of onset of these symptoms has yet been reported in cats.

We recently found that the adrenal glands of cats with FIC were smaller than those of healthy cats, and less responsive to adrenocorticotropic hormone [39]. Microscopic examination of the glands revealed an absence of hemorrhage, inflammation, infection, or necrosis to explain the reduced size, suggesting the presence of mild primary adrenal insufficiency or decreased adrenal reserve in these cats. These findings provided early circumstantial evidence that vulnerability for IC, and by extension other comorbid MUS, might have developmental antecedents.

In addition to humans and cats with IC, hypocortisolism has also been identified in patients with chronic pelvic pain, chronic fatigue syndrome, fibromyalgia and post-traumatic stress disorder. Hypocortisolism also seems more common in women than in men, although its presence has been reported in a subset of men with metabolic syndrome [40]. It has been suggested that hypocortisolism may be a protective response to reduce the damaging effects of the glucocorticoid response to daily hassles, albeit at the expense of symptoms such as high stress sensitivity, pain, and fatigue [41]. This effect could be exaggerated in individuals with preexisting (developmental) vulnerabilities.

Evidence of adverse early experiences in patients with IC $[42,43]$ and other MUS [44-46] suggests the likelihood of environmental instability in the lives of their parents [44], which may have affected the development of their offspring. The small adrenal glands we found in cats and adrenocortical hormone abnormalities present in some patients with MUS during stressful episodes [36, 41, $47,48]$ may be stigmata of such events. The effects of stressors on fetal adrenal development in other species seem to depend both on the timing and magnitude of exposure to products of the maternal stress response in relation to the activity of the developmental 'programs' that determine the maturation of the various body systems during gestation and early postnatal development [49]. If exposed before initiation of a developmental program, there may be no effect. During the critical period while the adrenocortical maturation program is running however, studies in rodents [50,51], carnivores [52], and primates $[53,54]$ all have found maternal stressors to reduce adrenal size in the affected offspring. If a sufficiently severe stress response occurs after the critical period of adrenocortical development, adrenal size and subsequent adrenocortical responses to stress may be increased [55].

In addition to epigenetic alterations in gene expression, a variety of genetic polymorphisms that affect stress responsiveness also have been identified in humans [56], including the catechol-O-methyltransferase [57], serotonin transporter [58], and $\alpha_{2}$-adrenergic receptor genes [59]. Once pregnant, exposure of mothers carrying such polymorphisms to significant salient stressors may increase the risk for exposure of a developing fetus to products of the stress response, enhancing the chances of sensitizing the stress response system of these offspring. Such a mechanism has been identified in other disorders. For example, Beversdorf et al. [60] recently reported that a history of prenatal stress peaking at 25-28 weeks gestation was associated with an increased risk for development of autism. In a follow-up study [61], surveys for a history of prenatal stress combined with genotyping for presence of the long and short alleles of the serotonin transporter gene promoter revealed that the presence of a history of prenatal stress was significantly associated with the presence of the short allele of the promoter in mothers of autistic children, suggesting that the enhanced stress sensitivity associated with the presence of this allele [62] may serve as a maternal stress-response risk factor for the development of autism in their offspring. Such studies are needed in patients with MUS to test the relevance of these provocative findings to this category of disorders.

In addition to alterations in the components of the stress response system distal to the hypothalamus, changes in proximal structures that modulate its activity also may play a role in MUS. For example, the medial prefrontal cortex is known to regulate the neuroendocrine and autonomic output of the hypothalamus [63]. Many critical periods of development occur during brain maturation [64], which have been shown to be affected by maternal stressors [12]. Reser [65] recently proposed that one result of this process is a decrease in cerebral metabolic rates to conserve energy in unpredictable environments.

Cognitive function too is influenced by both genetic [66] and epigenetic [67] factors. Many studies have also shown that cognitive factors, such as classical and operant conditioning, attentional bias and memory, can influence the onset, development and maintenance of MUS 
[68-70]. Moreover, studies of the importance of cognitive factors such as attention to behavioral contingencies in situations in which potentially traumatic events occur have shown that it is not the physical event(s) per se that determine the immediate and long-term consequences, but the individual's expectations and ability to cope with the threatening situation [71].

\section{Implications for Therapy}

Consideration of developmental influences on MUS may have important therapeutic implications. For example, drugs to reverse the processes of EMGEX also are under active investigation, as cancer chemotherapeutic agents [72-74]. If some of the MUS turn out to have developmental origins, these drugs may be appropriate to consider for their therapeutic potential in these patients. This hypothesis also may explain the effectiveness of such 'central' approaches to therapy as tricyclic antidepressants (which among other actions attenuate catecholaminergic output) [75-78], hypnosis [79, 80], effective doctor-patient communication [81], use of psychiatrists as consultants in the general practice setting [82], and various other psychological approaches to treatment $[2$, 83-88] that might reduce the perception of threat in amenable patients. We also have successfully used an 'environmental' approach to therapy for cats with FIC [89]; EMGEX is one candidate mechanism for the effects of environmental enrichment [90].

\section{Conclusion}

In summary, viewing the MUS from the perspective of underlying developmental influences involving EMGEX that affect function of a variety of organs based on familial (genetic and environmental) predispositions rather than from the traditional viewpoint of isolated organ-originating diseases has at least two important implications. First, it provides a more parsimonious explanation for many findings that have been quite difficult to account for, including the unfortunate lack of beneficial effect of therapies directed at the peripheral organ of interest to a particular medical subspecialty [91, 92], the presence of multiple comorbid disorders in many patients with MUS, but not in patients with other individual organ diseases, the unpredictable order of appearance of the comorbidities, and the altered functioning of the hypothalamic-pituitary-adrenal and autonomic axes of the stress response system. Second, and more importantly, it invites investigation of new areas of therapy that may otherwise escape consideration.

\section{Acknowledgement}

I thank Dr. Dirk Hellhammer for his patience and many helpful suggestions for improving earlier drafts of the manuscript.

\section{References}

1 Wessely S, Nimnuan C, Sharpe M: Functional somatic syndromes: one or many? Lancet 1999;354:936-939.

- Fava GA, Sonino N: The clinical domains of psychosomatic medicine. J Clin Psychiatry 2005;66:849-858.

-3 Richardson RD, Engel CC Jr: Evaluation and management of medically unexplained physical symptoms. Neurologist 2004;10: $18-30$.

4 Kroenke K: Studying symptoms: sampling and measurement issues. Ann Intern Med 2001;134:844-853.

5 Nimnuan C, Hotopf M, Wessely S: Medically unexplained symptoms - an epidemiological study in seven specialities. J Psychosom Res 2001;51:361-367.

6 Wessely S, White PD: There is only one functional somatic syndrome. Br J Psychiatry 2004; 185:95-96.
7 Fink P, Toft T, Hansen MS, Ornbol E, Olesen F: Symptoms and syndromes of bodily distress: an exploratory study of 978 internal medical, neurological, and primary care patients. Psychosom Med 2007;69:30-39.

$\checkmark 8$ Schur EA, Afari N, Furberg H, Olarte M, Goldberg J, Sullivan PF, Buchwald D: Feeling bad in more ways than one: comorbidity patterns of medically unexplained and psychiatric conditions. J Gen Intern Med 2007;22: 818-821.

9 Godfrey K: The 'developmental origins' hypothesis: epidemiology; in Gluckman PD, Hanson MA (eds): Developmental Origins of Health and Disease. Cambridge, Cambridge University Press, 2006, pp 6-32.

10 Gluckman PD, Hanson MA: Mismatch: Why Our World No Longer Fits Our Bodies. Oxford, Oxford University Press, 2006.

-11 Meaney MJ, Szyf M, Seckl JR: Epigenetic mechanisms of perinatal programming of hypothalamic-pituitary-adrenal function and health. Trends Mol Med 2007;13:269_ 277.
-12 Van den Bergh BR, Mulder EJ, Mennes M, Glover V: Antenatal maternal anxiety and stress and the neurobehavioural development of the fetus and child: links and possible mechanisms. A review. Neurosci Biobehav Rev 2005;29:237-258.

13 Jones A, Beda A, Ward AM, Osmond C, Phillips DI, Moore VM, Simpson DM: Size at birth and autonomic function during psychological stress. Hypertension 2007;49: 548-555.

14 Merlot E, Couret D, Otten W: Prenatal stress, fetal imprinting and immunity. Brain Behav Immun 2008;22:42-51.

15 Bateson P, Barker D, Clutton-Brock T, Deb D, D’Udine B, Foley RA, Gluckman P, Godfrey K, Kirkwood T, Lahr MM, McNamara J, Metcalfe NB, Monaghan P, Spencer HG, Sultan SE: Developmental plasticity and human health. Nature 2004;430:419-421.

16 McEwen BS: Physiology and neurobiology of stress and adaptation: central role of the brain. Physiol Rev 2007;87:873-904 
17 Cohen S, Hamrick N: Stable individual differences in physiological response to stressors: Implications for stress-elicited changes in immune related health. Brain Behav Immun 2003;17:407-414.

18 Burleson MH, Poehlmann KM, Hawkley LC, Ernst JM, Berntson GG, Malarkey WB, Kiecolt-Glaser JK, Glaser R, Cacioppo JT: Neuroendocrine and cardiovascular reactivity to stress in mid-aged and older women: long-term temporal consistency of individual differences. Psychophysiology 2003;40: 358-369.

19 Dhabhar FS, McEwen BS, Spencer RL: Stressresponse, adrenal-steroid receptor levels and corticosteroid-binding globulin levels - a comparison between Sprague-Dawley, Fischer-344 and Lewis rats. Brain Res 1993; 616:89-98.

20 Buskila D: Genetics of chronic pain states. Best Pract Res Clin Rheumatol 2007;21:535547.

21 Turk DC: The potential of treatment matching for subgroups of patients with chronic pain - lumping versus splitting. Clin J Pain 2005;21:44-55.

22 Weaver ICG, Cervoni N, Champagne FA, D’Alessio AC, Sharma S, Seckl JR, Dymov S, Szyf M, Meaney MJ: Epigenetic programming by maternal behavior. Nat Neurosci 2004;7:847-854.

23 Feinberg AP: Epigenetics at the epicenter of modern medicine. JAMA 2008;299:13451350.

24 Fowden AL, Giussani DA, Forhead AJ: Endocrine and metabolic programming during intrauterine development. Early Hum Dev 2005;81:723-734.

-25 Seckl JR: Prenatal glucocorticoids and longterm programming. Eur J Endocrinol 2004; 151(suppl 3):U49-U62.

26 Meaney MJ, Szyf M: Maternal care as a model for experience-dependent chromatin plasticity? Trends Neurosci 2005;28:456-463.

27 Hanno PM: Painful bladder syndrome/interstitial cystitis and related diseases; in Wein AJ, Kavoussi LR, Novick AC, partin AW, Peters CA (eds): Campbell-Walsh Urology. Philadelphia, Saunders, 2007, vol 1, pp 330-370.

28 Kennedy CM, Bradley CS, Galask RP, Nygaard IE: Risk factors for painful bladder syndrome in women seeking gynecologic care. Int Urogynecol J Pelvic Floor Dysfunct 2006;17:73-78.

29 Whitehead WE, Palsson O, Jones KR: Systematic review of the comorbidity of irritable bowel syndrome with other disorders: what are the causes and implications? Gastroenterology 2002;122:1140-1156.

- 30 Clauw DJ, Schmidt M, Radulovic D, Singer A, Katz P, Bresette J: The relationship between fibromyalgia and interstitial cystitis. J Psychiatr Res 1997;31:125-131.
31 Clauw DJ, Chrousos GP: Chronic pain and fatigue syndromes: overlapping clinical and neuroendocrine features and potential pathogenic mechanisms. Neuroimmunomodulation 1997;4:134-153.

32 Weissman MM, Gross R, Fyer A, Heiman GA, Gameroff MJ, Hodge SE, Kaufman D, Kaplan SA: Interstitial cystitis and panic disorder: a potential genetic syndrome. Arch Gen Psychiatry 2004;61:273-279.

33 Talati A, Ponniah K, Strug LJ, Hodge SE, Fyer AJ, Weissman MM: Panic disorder, social anxiety disorder, and a possible medical syndrome previously linked to chromosome 13. Biol Psychiatry 2008;63:594-601.

34 Buffington CAT, Chew DJ, Woodworth BE: Feline interstitial cystitis. J Am Vet Med Assoc 1999;215:682-687.

35 Buffington CAT, Chew DJ, Woodworth BE, DiBartola SP: Idiopathic cystitis in cats: An animal model of interstitial cystitis; in Sant GR (ed): Interstitial Cystitis. Philadelphia, Lippincott-Raven, 1997, pp 25-31.

36 Buffington CAT: Comorbidity of interstitial cystitis with other unexplained clinical conditions. J Urol 2004;172:1242-1248.

37 Buffington CAT, Westropp JL, Chew DJ, Bolus RR: A case-control study of indoorhoused cats with lower urinary tract signs. J Am Vet Med Assoc 2006;228:722-725.

-38 Buffington CAT: External and internal influences on disease risk in cats. J Am Vet Med Assoc 2002;220:994-1002.

39 Westropp JL, Welk KA, Buffington CAT: Small adrenal glands in cats with feline interstitial cystitis. J Urol 2003; 170:24942497.

40 Bjorntorp P, Rosmond R: Neuroendocrine abnormalities in visceral obesity. Int $\mathrm{J}$ Obes 2000;24:S80-S85.

-41 Fries E, Hesse J, Hellhammer J, Hellhammer DH: A new view on hypocortisolism. Psychoneuroendocrinology 2005;30:10101016.

42 Oemler M, Grabhorn R, Vahlensieck W, Jonas D, Bickeboller R: Psychosocial aspects of interstitial cystitis: do biographical factors have a relevant impact on the disease course? Urologe A 2006;45:728-733.

43 Peters KM, Kalinowski SE, Carrico DJ, Ibrahim IA, Diokno AC: Fact or fiction - is abuse prevalent in patients with interstitial cystitis? Results from a community survey and clinic population. J Urol 2007;178:891-895.

44 Lackner JM, Gudleski GD, Blanchard EB: Beyond abuse: the association among parenting style, abdominal pain, and somatization in IBS patients. Behav Res Ther 2004;42: $41-56$.

45 Weissbecker I, Floyd A, Dedert E, Salmon P, Sephton S: Childhood trauma and diurnal cortisol disruption in fibromyalgia syndrome. Psychoneuroendocrinology 2006;31: 312-324.
46 Cromer KR, Sachs-Ericsson N: The association between childhood abuse, PTSD, and the occurrence of adult health problems: moderation via current life stress. J Trauma Stress 2006;19:967-971.

47 Heim C, Ehlert U, Hellhammer DH: The potential role of hypocortisolism in the pathophysiology of stress-related bodily disorders. Psychoneuroendocrinology 2000;25:1-35.

48 Bohmelt AH, Nater UM, Franke S, Hellhammer DH, Ehlert U: Basal and stimulated hypothalamic-pituitary-adrenal axis activity in patients with functional gastrointestinal disorders and healthy controls. Psychosom Med 2005;67:288-294.

49 Gluckman PD, Hanson MA: The Fetal Matrix: Evolution, Development and Disease. Cambridge, Cambridge University Press, 2005.

50 Fameli M, Kitraki E, Stylianopoulou F: Effects of hyperactivity of the maternal hypothalamic-pituitary-adrenal (HPA) axis during pregnancy on the development of the HPA axis and brain monoamines of the offspring. Int J Dev Neurosci 1994;12:651-659.

51 Cadet R, Pradier P, Dalle M, Delost P: Effects of prenatal maternal stress on the pituitary adrenocortical reactivity in guinea-pig pups. J Dev Physiol 1986;8:467-475.

-52 Braastad BO, Osadchuk LV, Lund G, Bakken M: Effects of prenatal handling stress on adrenal weight and function and behaviour in novel situations in blue fox cubs (Alopex lagopus). Appl Anim Behav Sci 1998;57:157169.

53 Challis JRG, Davies IA, Benirschke K, Hendrickx AG, Ryan KJ: The effects of dexamethasone on plasma steroid levels and fetal adrenal histology in the pregnant rhesus monkey. Endocrinology 1974;95:13001305

-54 Leavitt MG, Aberdeen GW, Burch MG, Albrecht ED, Pepe GJ: Inhibition of fetal adrenal adrenocorticotropin receptor messenger ribonucleic acid expression by betamethasone administration to the baboon fetus in late gestation. Endocrinology 1997;138: 2705-2712.

55 Matthews SG: Early programming of the hypothalamo-pituitary-adrenal axis. Trends Endocrinol Metab 2002;13:373-380.

56 Wust S, Federenko IS, Van Rossum EFC, Koper JW, Kumsta R, Entringer S, Hellhammer DH: A psychobiological perspective on genetic determinants of hypothalamus-pituitary-adrenal axis activity. Ann NY Acad Sci 2004;1032:52-62.

57 Stein DJ, Newman TK, Savitz J, Ramesar R: Warriors versus worriers. The role of COMT gene variants. CNS Spectr 2006;11:745-748.

58 Jacobs N, Kenis G, Peeters F, Derom C, Vlietinck R, van Os J: Stress-related negative affectivity and genetically altered serotonin transporter function - evidence of synergism in shaping risk of depression. Arch Gen Psychiatry 2006;63:989-996. 
59 Rosmond R, Bouchard C, Bjorntorp P: A C$1291 \mathrm{G}$ polymorphism in the alpha2A-adrenergic receptor gene (ADRA2A) promoter is associated with cortisol escape from dexamethasone and elevated glucose levels. J Intern Med 2002;251:252-257.

-60 Beversdorf DQ, Manning SE, Hillier A, Anderson SL, Nordgren RE, Walters SE, Nagaraja HN, Cooley WC, Gaelic SE, Bauman ML: Timing of prenatal stressors and autism. J Autism Dev Disord 2005;35:471-478.

61 Beversdorf D, Birmingham DJ, Arasu V, Alexander JK, Campbell HL, White CA, Hillier A, Bauman M: Prenatal stress and maternal serotonin transporter protein polymorphisms in autism (abstract S27.005). 58th Annu Meet Am Acad Neurol, Boston, 2007.

-62 Taylor SE, Way BM, Welch WT, Hilmert CJ, Lehman BJ, Eisenberger NI: Early family environment, current adversity, the serotonin transporter promoter polymorphism, and depressive symptomatology. Biol Psychiatry 2006;60:671-676.

63 Radley JJ, Arias CM, Sawchenko PE: Regional differentiation of the medial prefrontal cortex in regulating adaptive responses to acute emotional stress. J Neurosci 2006;26: 12967-12976.

-64 Andersen SL: Trajectories of brain development: point of vulnerability or window of opportunity? Neurosci Biobehav Rev 2003; 27:3-18.

65 Reser JE: Evolutionary neuropathology and congenital mental retardation: environmental cues predictive of maternal deprivation influence the fetus to minimize cerebral metabolism in order to express bioenergetic thrift. Med Hypotheses 2006;67:529-544.

-66 Matzel LD, Townsend DA, Grossman H, Han YR, Hale G, Zappulla M, Light K, Kolata S: Exploration in outbred mice covaries with general learning abilities irrespective of stress reactivity, emotionality, and physical attributes. Neurobiol Learn Mem 2006;86: 228-240.

67 Chwang WB, O’Riordan KJ, Levenson JM, Sweatt JD: ERK/MAPK regulates hippocampal histone phosphorylation following contextual fear conditioning. Learn Mem 2006; 13:322-328.

-68 Afzal M, Potokar JP, Probert CS, Munafo MR: Selective processing of gastrointestinal symptom-related stimuli in irritable bowel syndrome. Psychosom Med 2006;68:758761.
69 Enck P, Klosterhalfen S: The placebo response in functional bowel disorders: perspectives and putative mechanisms. Neurogastroenterol Motil 2005;17:325-331.

70 Glass JM: Cognitive dysfunction in fibromyalgia and chronic fatigue syndrome: new trends and future directions. Curr Rheumatol Rep 2006;8:425-429.

71 Overmier JB, Murison R: Trauma and resulting sensitization effects are modulated by psychological factors. Psychoneuroendocrinology 2005;30:965-973.

72 Lu Q, Qiu X, Hu N, Wen H, Su Y, Richardson BC: Epigenetics, disease, and therapeutic interventions. Ageing Res Rev 2006;5:449467.

73 Barnes PJ, Adcock IM, Ito K: Histone acetylation and deacetylation: importance in inflammatory lung diseases. Eur Respir J 2005; 25:552-563.

74 Bhattacharyya SN, Habermacher R, Martine U, Closs EI, Filipowicz W: Relief of microrna-mediated translational repression in human cells subjected to stress. Cell 2006;125: 1111-1124.

75 O'Malley PG, Jackson JL, Santoro J, Tomkins G, Balden E, Kroenke K: Antidepressant therapy for unexplained symptoms and symptom syndromes. J Fam Pract 1999;48: 980-990.

76 van Ophoven A, Hertle L: Long-term results of amitriptyline treatment for interstitial cystitis. J Urol 2005;174:1837-1840.

77 Crowell MD, Jones MP, Harris LA, Dineen TN, Schettler VA, Olden KW: Antidepressants in the treatment of irritable bowel syndrome and visceral pain syndromes. Curr Opin Investig Drugs 2004;5:736-742.

78 Goldenberg DL: Pharmacological treatment of fibromyalgia and other chronic musculoskeletal pain. Best Pract Res Clin Rheumatol 2007;21:499-511.

79 Gonsalkorale WM, Houghton LA, Whorwell PJ: Hypnotherapy in irritable bowel syndrome: a large-scale audit of a clinical service with examination of factors influencing responsiveness. Am J Gastroenterol 2002;97: 954-961.

80 Jensen M, Patterson DR: Hypnotic treatment of chronic pain. J Behav Med 2006;29:95124.

81 Spiegel BM, Naliboff B, Mayer EA, Bolus R, Gralnek IM, Shekelle P: The effectiveness of a model physician-patient relationship versus usual care in irritable bowel syndrome (IBS): a randomized controlled trial. Gastroenterology 2006;130(suppl 2):A112.
82 van der Feltz-Cornelis CM, van Oppen P, Ader HJ, van Dyck R: Randomised controlled trial of a collaborative care model with psychiatric consultation for persistent medically unexplained symptoms in general practice. Psychother Psychosom 2006;75: 282-289.

83 Grossman P, Tiefenthaler-Gilmer U, Raysz A, Kesper U: Mindfulness training as an intervention for fibromyalgia: Evidence of postintervention and 3-year follow-up benefits in well-being. Psychother Psychosom 2007; 76:226-233.

84 Walach H, Bosch H, Lewith G, Naumann J, Schwarzer B, Falk S, Kohls N, Haraldsson E, Wiesendanger $\mathrm{H}$, Nordmann A, Tomasson $\mathrm{H}$, Prescott P, Bucher HC: Effectiveness of distant healing for patients with chronic fatigue syndrome: a randomised controlled partially blinded trial (EUHEALS). Psychother Psychosom 2008;77:158-166.

85 Walach H, Jonas WB: Placebo research: the evidence base for harnessing self-healing capacities. J Altern Complement Med 2004; 10(suppl 1):S103-S112.

86 Puetz TW, Flowers SS, O’Connor PJ: A randomized controlled trial of the effect of aerobic exercise training on feelings of energy and fatigue in sedentary young adults with persistent fatigue. Psychother Psychosom 2008;77:167-174.

87 Schweickhardt A, Larisch A, Wirshing M, Fritzsche K: Short-term psychotherapeutic interventions for somatizing patients in the general hospital. Psychother Psychosom 2007:76:339-346

$>88$ Sonino N, Fava GA: Rehabilitation in endocrine patients. Psychother Psychosom 2007; 76:319-324

89 Buffington CAT, Westropp JL, Chew DJ, Bolus RR: Clinical evaluation of multimodal environmental modification in the management of cats with lower urinary tract signs. J Feline Med Surg 2006;8:261-268.

$>90$ Nithianantharajah J, Hannan AJ: Enriched environments, experience-dependent plasticity and disorders of the nervous system. Nat Rev Neurosci 2006;7:697-709.

91 Dimitrakov J, Kroenke K, Steers WD, Berde C, Zurakowski D, Freeman MR, Jackson JL: Pharmacologic management of painful bladder syndrome/interstitial cystitis: a systematic review. Arch Intern Med 2007;167:19221929.

92 Dawson TE, Jamison J: Intravesical treatments for painful bladder syndrome/interstitial cystitis. Cochrane Database Syst Rev 2007;4:CD006113. 